\title{
Equivalent temperature for design of asphalt pavements in Poland
}

\author{
Marek Pszczola* \\ Faculty of Civil and Environmental Engineering, Gdansk University of Technology, \\ Narutowicza 11/12, 80-233 Gdansk, Poland
}

\begin{abstract}
The paper presents application of equivalent temperature for design of asphalt pavements. The calculation methods of equivalent temperature: the Shell method, the French method, the methods that use the AASHTO and the Asphalt Institute fatigue criteria were presented. The results of calculations of equivalent temperature for Polish climatic conditions were presented and discussed. It was shown that different asphalt pavement design methods and utilization of Polish climatic data resulted in various calculated values of equivalent temperature that could be used in the design process.
\end{abstract}

\section{Introduction}

One of the most important factor that influences the behaviour of the road pavements is temperature. In the case of asphalt pavements temperature affects the mechanical characteristics of the pavement [1-3]. Cyclical variations of temperature cause shrinkage cracks in materials treated with hydraulic binders. Also, thermal gradients cause strains in the concrete slabs in rigid pavements. In the practice of asphalt pavements design process, in most cases calculations are carried out with consideration of an equivalent constant temperature. The behaviour of asphalt layers in terms of deformation and fatigue depends on temperature, stress levels and damage level of the asphalt pavement. According to French practice [4] structural design is carried out for the constant temperature, referred to as the equivalent temperature $\theta_{\text {eq. }}$. The equivalent temperature is defined in case when the cumulative damage in the asphalt pavement over a year, for a given temperature distribution, is equal to the damage that the pavement would undergo with the same traffic but for the constant temperature $\theta$ eq. The equivalent temperature is determined by applying Miner's law [5]. According to the Shell procedure [6,7] the equivalent temperature can be also called as „effective temperature". The effective stress generated in the pavement structure characterized by a single temperature model corresponds to the stresses calculated on the basis of models set up in accordance with various temperature values. Calculation can be performed according to the equation (1):

$$
N_{e f f}=\frac{1}{\frac{1}{n} \sum_{i=1}^{n}\left(\frac{1}{N_{i}}\right)}
$$

where:

$\mathrm{N}_{\text {eff }}$ - effective cycle number (the effective design life) in effective single temperature applied for the design pavement according to Miner's hypothesis,
$\mathrm{N}_{\mathrm{i}}$ - actual allowed cycle number calculated on the basis of various temperatures,

n - number of temperature gradients.

The objective of the paper is to determine the equivalent temperature values on the basis of meteorological data for selected locations in Poland with the use of mechanistic-empirical methods. The temperature data were collected and analysed for the following 32 years period of time: from the beginning of 1985 to the end of 2016. The location of meteorological stations was chosen to represent all the Polish territory.

\section{Methods}

\subsection{The Shell method}

Analysis of equivalent temperature for design of asphalt pavement according to the Shell procedure [6] consisted following steps:

1. Determination of the mean monthly air temperature (MMAT) for each month during entire period: from January 1985 to December 2016.

2. For each MMAT value the „Weighting Factor“ was derived from Figure 1.

\footnotetext{
* Corresponding author: marek.pszczola @ pg.edu.pl
} 


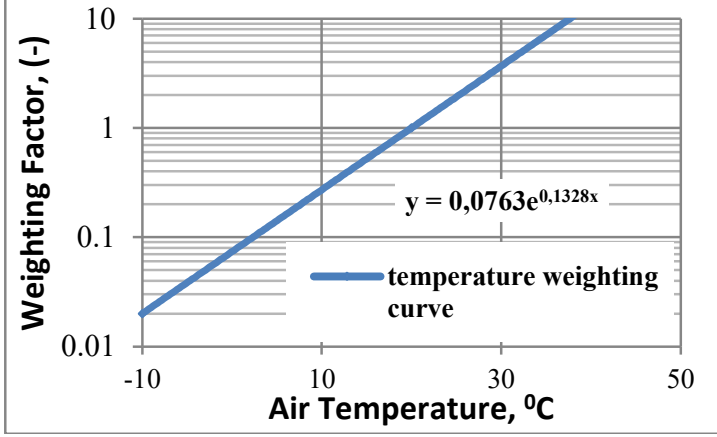

Fig. 1. Temperature weighting curve, according to Shell method [6]

3. Calculation of the annual average weighting factor for each analysed location.

4. Determination of the equivalent temperature values (effective Mean Annual Air Temperature MAAT) on the basis of annual average weighting factor for pavement structure: a) $8 \mathrm{~cm}$ asphalt layers and 20 crushed aggregate base course (KR2); b) $20 \mathrm{~cm}$ asphalt layers and 20 crushed aggregate base course (KR4); c) $24 \mathrm{~cm}$ asphalt layers and 20 crushed aggregate base course (KR6).

\subsection{The French method}

With application of the French method [4] the calculations of equivalent temperature were conducted according to the following equation (2):

$\sum_{i} \frac{n_{i}\left(\theta_{i}\right)}{N_{i}\left(\theta_{i}\right)}=\frac{\sum_{i} n_{i}\left(\theta_{i}\right)}{N\left(\theta_{e q}\right)}$

where:

$\theta_{\mathrm{i}} \quad$ - pavement temperature distribution during a year, $\mathrm{N}_{\mathrm{i}}\left(\theta_{\mathrm{i}}\right)$ - number of loadings causing failure due to fatigue for the level of strain $\varepsilon\left(\theta_{i}\right)$,

$\varepsilon\left(\theta_{i}\right)$ - tensile strain in the pavement under the standard axle,

$\mathrm{n}_{\mathrm{i}}\left(\theta_{\mathrm{i}}\right)$ - number of temperature $\theta_{\mathrm{i}}$ gradients,

$\theta_{\text {eq }}$ - equivalent temperature, $\left[{ }^{\circ} \mathrm{C}\right]$.

After calculating the elementary damage $1 / \mathrm{N}(\theta \mathrm{eq})$, equivalent temperature $\theta$ eq was obtained from the curve giving the variation in damage according to temperature distribution $\theta \mathrm{i}$. The calculation of the equivalent temperature according to the French method was performed using the following procedure:

1. Determination of the mean monthly air temperature (MMAT) distribution and mean monthly pavement temperature (MMPT) in $5^{\circ} \mathrm{C}$ intervals. Determination of the stiffness modulus of asphalt base course for each temperature interval.

2. Calculation of horizontal strain at the bottom of asphalt layers at a certain temperature (at certain stiffness modulus of asphalt mixture).

3. Assumption was made according to the literature [8] that the value of strain $\varepsilon_{6}$ in millionth load cycle (assumed for temperature up to $+10^{\circ} \mathrm{C}$ ) $\varepsilon_{6}=115 \times 10^{-6}$. Other $\varepsilon_{6}$ strain values for other temperatures were estimated due to the lack of laboratory results. In addition the laboratory fatigue test method and shape of samples that are typically used in France are different from those used in Poland.

4. Calculation of the weighted average fatigue damage based on pavement temperature distribution and fatigue damage in each temperature interval.

5. Determination of the equivalent temperature based on the calculated average fatigue damage according to a particular function of the temperature and fatigue damage.

\subsection{Method with use of Asphalt Institute and AASHTO 2004 fatigue criteria}

Determination of the equivalent temperature with use of Asphalt Institute [8, 10] and AASHTO 2004 [12] fatigue criteria included the following steps:

1. Determination of mean monthly air temperatures (MMAT) based on the temperature data from meteorological stations.

2. Calculation of the mean monthly pavement temperature according to the equation (3) developed originally by Witczak [10]:

$M M P T=M M A T \cdot\left[1+\frac{1}{z+4}\right]-\frac{34}{z+4}+6$

where:

MMPT - mean monthly pavement temperature, ('Fahrenheit),

MMAT - mean monthly air temperature, ( ${ }^{\circ}$ Fahrenheit $)$, $\mathrm{z}$ - depth below the pavement surface, (inch).

3. Calculation of fatigue life with the use of the fatigue cracks criteria of the analysed asphalt pavement. The calculations were conducted for the temperature range from $-20^{\circ} \mathrm{C}$ to $+30^{\circ} \mathrm{C}$ with $5^{\circ} \mathrm{C}$ intervals. Stiffness moduli of asphalt mixtures were determined using the software program Shell-BANDS. To simplify the calculation procedure the wheel load was assumed to $50 \mathrm{kN}$ as the value typically applied during road pavements design process. Frequency of traffic was assumed as uniform flow during entire year. Calculation of fatigue life during entire year was performed using the following equation (4):

$N_{\text {year }}=\frac{100}{\left(\frac{\% \text { traffic1 } 1}{N 1}+\frac{\% \text { traffic } 2}{N 2}+\cdots+\frac{\% \text { traffic } 12}{N 12}\right)}$

where:

$\mathrm{N}_{\text {year }} \quad$ - fatigue life of asphalt pavement during entire year,

$\%$ traffic 1 - percentage of traffic in January (the 1 st month),

$\%$ traffic 2 - the same but in February (the 2nd month), $\%$ traffic12- the same but in December (the 12th month), $\mathrm{N} 1, \mathrm{~N} 2$...N12 - fatigue life calculated in each month. 4. On the basis of fatigue curve determined for each mean monthly temperature one annual equivalent temperature was assigned as a value in which fatigue life is equal to a value obtained from different temperatures.

\section{Analysis of temperature data}

Temperature data that were required for the calculation of equivalent temperature were obtained from 
the Institute of Meteorology and Water Management (IMGW), Polish National Research Institute from period of time from January 1985 to December 2016. The first step of temperature data analysis concerned all the 65 meteorological stations located in Poland. For further analysis 10 meteorological stations were selected. The meteorological stations with gaps in measurement data and located at mountain peaks, for ex. Sniezka or Kasprowy Wierch were excluded from the analysis.. The location of meteorological stations located evenly on the Polish territory is presented in Figure 2.

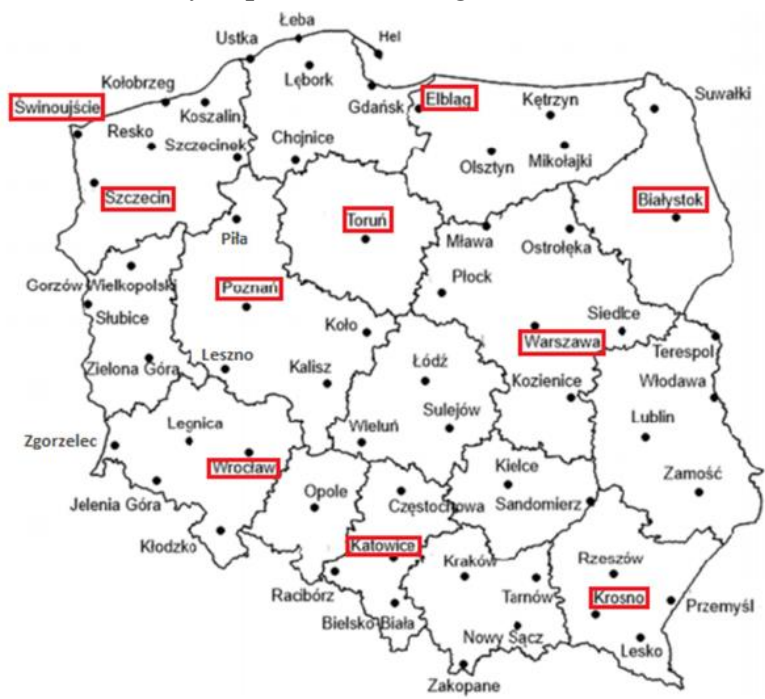

Fig. 2. The location of meteorological stations, [11]

The results of mean value analysis of air temperature from January 1985 to December 2016 were shown in Table 1.

Table 1. The results of mean value analysis of air temperature from January 1985 to December 2016, [11]

\begin{tabular}{|c|c|c|c|c|c|c|c|c|c|c|c|c|}
\hline \multirow[b]{2}{*}{ Location } & \multicolumn{12}{|c|}{ Mean values of air temperature from 1985 to $2016,{ }^{\circ} \mathrm{C}$} \\
\hline & 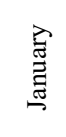 & 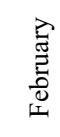 & 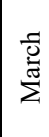 & $\begin{array}{l}\overline{\vec{z}} \\
\overline{4}\end{array}$ & $\stackrel{\overparen{\Sigma}}{\grave{\Sigma}}$ & 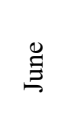 & $\stackrel{\gtrsim}{\Xi}$ & 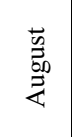 & 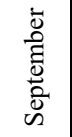 & $\begin{array}{l}\dot{0} \\
\text { 0. } \\
\stackrel{0}{0}\end{array}$ & $\begin{array}{l}\bar{\nabla} \\
\bar{\Xi} \\
\text { ठे } \\
z\end{array}$ & $\begin{array}{l}\bar{\Xi} \\
\text { हี } \\
\text { ठू. } \\
\text { ص. }\end{array}$ \\
\hline Bialy & & & & 7.6 & 13.1 & 16.0 & 18.2 & 17.1 & 12.2 & 7.2 & 2.3 & -1.5 \\
\hline Elblag & -1.7 & -0.7 & 2.6 & 8.0 & 12.9 & 15.7 & 18.2 & 17.7 & 13.4 & 8.5 & 3.6 & 0.1 \\
\hline Katow & -1.5 & -0.2 & 3.4 & 9.0 & 13.8 & 16.7 & 18.8 & 18.1 & 13.5 & 8.8 & 3.9 & -0.1 \\
\hline Krosno & -2.5 & -1.3 & & 8.7 & 13.5 & 16.4 & 18.4 & 18.0 & 13.3 & 8.7 & 3.7 & -1.1 \\
\hline Poznan & -0.8 & 0.2 & 3.6 & 9.1 & 14.2 & 16.8 & 19.2 & 18.5 & 13.9 & 8.9 & 3.9 & 0.8 \\
\hline Szczecin & 0.2 & 1.1 & 4.0 & 8.9 & 13.6 & 16.4 & 18.8 & 18.1 & 14.0 & 9.4 & 4.6 & 1.7 \\
\hline Swinoujscie & 0.4 & 1.1 & 3.6 & 7.6 & 12.1 & 15.5 & 18.0 & 17.8 & 14.2 & 9.6 & 4.8 & 1.8 \\
\hline Torun & -1.6 & -0.4 & 2.9 & 8.5 & 13.8 & 16.7 & 19.0 & 18.4 & 13.6 & 8.5 & 3.6 & 0.2 \\
\hline Warszawa & -1.9 & -0.8 & 2.9 & 8.9 & 14.3 & 17.1 & 19.4 & 18.6 & 13.6 & 8.4 & 3.4 & -0.2 \\
\hline Wroclaw & -0.5 & 0.6 & 4.1 & 9.3 & 14.2 & 17.1 & 19.3 & 18.7 & 14.2 & 9.3 & 4.3 & 1.0 \\
\hline
\end{tabular}

As an example the change of monthly temperature in every month of the analysed period of time from 1985 to 2016 and for Bialystok meteorological station is presented in Figure 3.

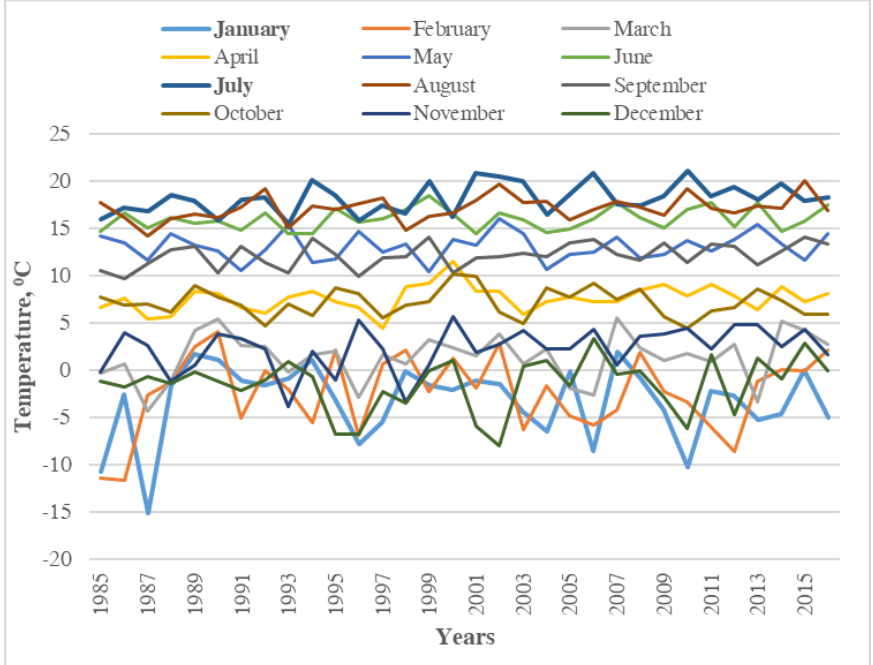

Fig. 3. An example the change of monthly temperature in every month of the analysed period of time from 1985 to 2016 and for Bialystok meteorological station

The results of air temperature measurements from meteorological station in Bialystok shown quite high variability between mean values of monthly temperatures during the past 32 years especially for winter months.

\section{Results and discussion}

The results of equivalent temperature calculations according to Shell method in the depth of $2 / 3$ of asphalt layers thickness were presented in Table 2 .

Table 2. The results of calculation of equivalent temperature according to Shell method

\begin{tabular}{|c|c|c|c|}
\hline \multirow{2}{*}{ Location } & \multicolumn{3}{|c|}{ Equivalent temperature, ${ }^{\circ} \mathrm{C}$} \\
\cline { 2 - 4 } & $\begin{array}{c}\mathrm{KR} 2 \\
(z=8 \mathrm{~cm})\end{array}$ & $\begin{array}{c}\mathrm{KR} 4 \\
(z=13 \mathrm{~cm})\end{array}$ & $\begin{array}{c}\mathrm{KR} 4 \\
(z=19 \mathrm{~cm})\end{array}$ \\
\hline Bialystok & 8.8 & 8.5 & 8.3 \\
\hline Elblag & 9.3 & 10.0 & 8.7 \\
\hline Katowice & 10.3 & 8.5 & 9.7 \\
\hline Krosno & 10.1 & 9.7 & 9.5 \\
\hline Poznan & 10.8 & 10.4 & 10.2 \\
\hline Szczecin & 10.5 & 10.2 & 9.9 \\
\hline Swinoujscie & 10.1 & 9.7 & 9.5 \\
\hline Torun & 10.3 & 10.0 & 9.7 \\
\hline Warszawa & 10.8 & 10.4 & 10.2 \\
\hline Wroclaw & 10.3 & 10.0 & 9.7 \\
\hline
\end{tabular}

The Shell method of calculations has shown that annual equivalent temperature that can be used for asphalt pavement design process is equal to $10^{\circ} \mathrm{C}$ (rounded to $\left.1,0^{\circ} \mathrm{C}\right)$.

In the French method of equivalent temperature calculation, the annual mean distribution of pavement temperature in the depth of $2 / 3 \mathrm{~h}$ of asphalt layers is given in Table 3. 
Table 3. Annual mean distribution of pavement temperature according to the French method

\begin{tabular}{|c|c|c|c|c|c|c|c|c|c|c|c|}
\hline $\begin{array}{c}\text { Temperature, } \\
{ }^{\circ} \mathrm{C}\end{array}$ & -20 & -15 & -10 & -5 & 0 & 5 & 10 & 15 & 20 & 25 & 30 \\
\hline $\begin{array}{c}\text { Duration } \\
\text { in year, \% }\end{array}$ & 0.3 & 0.7 & 2.4 & 6.0 & 14.7 & 17.1 & 15.2 & 17.4 & 17.0 & 8.2 & 1.0 \\
\hline
\end{tabular}

The stiffness moduli of asphalt base course $\mathrm{E}(\theta \mathrm{i})$ were calculated with the use of Shell-BISAR program. It was assumed that bitumen content in asphalt mixture $\mathrm{V}_{\mathrm{a}}$ is $9,5 \% \mathrm{v} / \mathrm{v}$ and voids content $\mathrm{V}_{\mathrm{v}}$ is $7 \% \mathrm{v} / \mathrm{v}$. To simplify the calculation procedure the wheel load was assumed $50 \mathrm{kN}$ as the value typically use during road pavements design.

The elementary damage was calculated according to French fatigue law from the equation (5):

$\mathrm{d}\left(\theta_{\mathrm{i}}\right)=\left(\frac{\varepsilon_{6}\left(\theta_{\mathrm{i}}\right)}{\varepsilon\left(\theta_{\mathrm{i}}\right)}\right)^{\frac{1}{b}} \cdot 10^{-6}$

where:

$\mathrm{d}(\theta \mathrm{i})$ - elementary damage at the temperature $\theta$,

$\varepsilon_{6}(\theta \mathrm{i})$ - strain after $10^{6}$ cycles,

$\varepsilon(\theta i)$ - tensile strain at the bottom of asphalt layers,

b - slope of fatigue curve $(b=-0,2)$

The results of calculation of elementary damage were presented in Table 4.

Table 4. Results of calculation of elementary damage according to French method

\begin{tabular}{|c|c|c|c|c|c|}
\hline $\begin{array}{l}\text { Tem- } \\
\text { perature }\end{array}$ & $\begin{array}{c}\text { Dura- } \\
\text { tion in } \\
\text { year } \\
\\
\mathrm{n}_{\mathrm{i}}\left(\theta_{\mathrm{i}}\right) \\
/ \Sigma \mathrm{n}_{\mathrm{i}}\left(\theta_{\mathrm{i}}\right) \\
{[\%]}\end{array}$ & $\begin{array}{l}\text { Stiff- } \\
\text { ness } \\
\text { mod- } \\
\text { ulus of } \\
\text { asphalt } \\
\text { base } \\
\text { course } \\
\\
\text { E }\left(\theta_{\mathrm{i}}\right) \\
{[\mathrm{MPa}]}\end{array}$ & $\begin{array}{c}\text { Tensile } \\
\text { strain at } \\
\text { the } \\
\text { bottom } \\
\text { of } \\
\text { asphalt } \\
\text { layers } \\
\varepsilon\left(\theta_{\mathrm{i}}\right) \\
\text { [ } \mu \text { strain] }\end{array}$ & $\begin{array}{c}\text { Strain } \\
\text { after } 10^{6} \\
\text { cycles }\end{array}$ & $\begin{array}{c}\text { Ele- } \\
\text { mentary } \\
\text { damage }\end{array}$ \\
\hline-20 & $0.3 \%$ & 31000 & 20 & 71 & 0.00161 \\
\hline-15 & $0.7 \%$ & 29000 & 21 & 73 & 0.00181 \\
\hline-10 & $2.4 \%$ & 26400 & 22 & 77 & 0.00213 \\
\hline-5 & $6.0 \%$ & 22600 & 26 & 83 & 0.00279 \\
\hline 0 & $14.7 \%$ & 18600 & 30 & 91 & 0.00389 \\
\hline 5 & $17.1 \%$ & 14800 & 36 & 102 & 0.00568 \\
\hline 10 & $15.2 \%$ & 11700 & 44 & 115 & 0.00829 \\
\hline 15 & $17.4 \%$ & 9310 & 53 & 129 & 0.01185 \\
\hline 20 & $17.0 \%$ & 6540 & 70 & 154 & 0.02001 \\
\hline 25 & $8.2 \%$ & 4330 & 97 & 189 & 0.03510 \\
\hline 30 & $1.0 \%$ & 2710 & 137 & 239 & 0.06128 \\
\hline
\end{tabular}

The elementary damage for equivalent temperature $1 / \mathrm{N}(\theta$ eq) was calculated from the equation (6):

$\frac{1}{\mathrm{~N}\left(\theta_{\mathrm{eq}}\right)}=\sum_{\mathrm{i}} \frac{\mathrm{n}_{\mathrm{i}}\left(\theta_{\mathrm{i}}\right)}{\sum_{\mathrm{i}} \mathrm{n}_{\mathrm{i}}\left(\theta_{\mathrm{i}}\right)} \mathrm{d}\left(\theta_{\mathrm{i}}\right)$

where:

$1 / \mathrm{N}(\theta$ eq $)$ - elementary damage for equivalent temperature,

$\mathrm{n}_{\mathrm{i}}\left(\theta_{\mathrm{i}}\right)$ - number of temperature $\theta \mathrm{i}$ gradients, $\mathrm{d}\left(\theta_{\mathrm{i}}\right)$ - elementary damage in temperature $\theta \mathrm{i}$.

The value of equivalent temperature for Polish temperature conditions according to calculations made with use of the French procedure is equal to $15^{\circ} \mathrm{C}$.

The results of calculation of asphalt mixture stiffness moduli according to method with use of the Asphalt Institute (IA) and AASHTO 2004 fatigue laws were presented in Table 5.

Table 5. The results of calculation of asphalt mixture stiffness moduli according to method with use of the IA and AASHTO 2004 fatigue laws

\begin{tabular}{|c|c|c|c|c|c|}
\hline \multirow{2}{*}{$\begin{array}{c}\text { Tempe- } \\
\text { rature, } \\
{ }^{\circ} \mathrm{C}\end{array}$} & $\begin{array}{c}|c| \\
\text { Stiffness } \\
\text { modulus of } \\
\text { bitumen, MPa }\end{array}$ & \multicolumn{3}{|c|}{$\begin{array}{c}\text { Stiffness modulus of asphalt } \\
\text { mixture, MPa }\end{array}$} \\
\cline { 3 - 6 } & $35 / 50$ & $50 / 70$ & $\begin{array}{c}\text { Wearing } \\
\text { course } \\
\text { AC11S } \\
50 / 70\end{array}$ & $\begin{array}{c}\text { Binder } \\
\text { course } \\
\text { AC16W } \\
35 / 50\end{array}$ & $\begin{array}{c}\text { Base } \\
\text { course } \\
\text { AC22P } \\
35 / 50\end{array}$ \\
\hline-20 & 1550 & 1480 & 27500 & 27700 & 29600 \\
\hline-15 & 1250 & 1160 & 25200 & 25700 & 27600 \\
\hline-10 & 953 & 858 & 22000 & 23200 & 25100 \\
\hline-5 & 679 & 605 & 18300 & 19400 & 21200 \\
\hline 0 & 451 & 388 & 14400 & 15700 & 17300 \\
\hline+5 & 278 & 240 & 11200 & 12200 & 13700 \\
\hline+10 & 169 & 144 & 8500 & 9380 & 10700 \\
\hline+15 & 103 & 78.1 & 5840 & 7240 & 8390 \\
\hline+20 & 57.5 & 39.3 & 3530 & 4900 & 5800 \\
\hline+25 & 29.4 & 18.2 & 2010 & 3120 & 3780 \\
\hline+30 & 13.7 & 8.22 & 1120 & 1860 & 2320 \\
\hline
\end{tabular}

The equivalent temperature calculations were conducted according to method with use of the Asphalt Institute fatigue criterion, form the equation (7):

$N_{b i t}=18,4 \cdot 6,167 \cdot 10^{-5} \cdot(10)^{4,84 \cdot\left(\frac{V_{a}}{V_{a}+V_{v}}-0,69\right)} \cdot S_{m}^{-0,854} \cdot \varepsilon_{b i t}^{-3,291}(7)$ where:

$\mathrm{V}_{\mathrm{a}}$ - bitumen content, [\%, v/v]

$\mathrm{V}_{\mathrm{v}}-$ voids content, $[\%, \mathrm{v} / \mathrm{v}]$

$\mathrm{S}_{\mathrm{m}}-$ stiffness modulus of asphalt mixture, [MPa]

$\varepsilon_{\text {bit }}-$ strain at the bottom of asphalt layers, [ $\mu$ strain $\left.\times 10^{-6}\right]$

In the next step of analysis the AASHTO 2004 fatigue criterion [12] was applied. It was assumed that the level of crack failure $\mathrm{FC}$ is equal to $15 \%$ and calculations were conducted according to equations (8-11):

$\mathrm{N}_{\mathrm{bit}}=7,3557 \cdot 10^{-6} \cdot \mathrm{C} \cdot \mathrm{k}_{1}^{\prime} \cdot\left(\frac{1}{\varepsilon_{\mathrm{asf}}}\right)^{3,9492} \cdot\left(\frac{1}{\mathrm{~S}_{\mathrm{m}}}\right)^{1,281}$ (8) where:

$\mathrm{C}=10^{\mathrm{M}}$

$\mathrm{M}=4,84 \cdot\left(\frac{\mathrm{V}_{\mathrm{a}}}{\mathrm{V}_{\mathrm{a}}+\mathrm{V}_{\mathrm{v}}}-0,69\right)$

$\mathrm{k}_{1}^{\prime}=\frac{1}{0,000398+\frac{0,003602}{1+\mathrm{e}^{11,02-1,374 \cdot \mathrm{h}}}}$

where:

$\mathrm{V}_{\mathrm{a}}$ - bitumen content, [\%, v/v]

$\mathrm{V}_{\mathrm{v}}-$ voids content, $[\%, \mathrm{v} / \mathrm{v}]$

$\mathrm{S}_{\mathrm{m}}-$ stiffness modulus of asphalt mixture, [MPa]

$\varepsilon_{\text {bit }}-$ strain at the bottom of asphalt layers, [ $\mu$ strain $\left.\times 10^{-6}\right]$ 
For the base course layer made of unbound crushed aggregate it was assumed that the value of modulus of elasticity is $400 \mathrm{MPa}$ and the Poisson ratio is equal to 0,3 . The resulting fatigue curve for traffic levels: KR2, KR4 and KR6 with use of the Asphalt Institute criterion was presented in Figure 5 and respectively with use of the AASHTO 2004 criterion was presented in Figure 6.

$y=0,018183 x^{4}+1,1096 x^{4}-16,594 x^{4}-234,724 x^{4}+15586,42 x^{2}-492872,44 x+7505867,91$

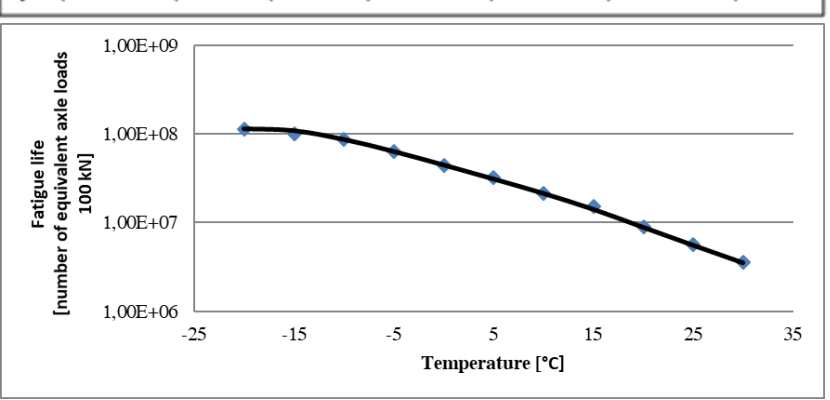

Fig. 5. The resulting fatigue curve from the calculations with use of Asphalt Institute criterion

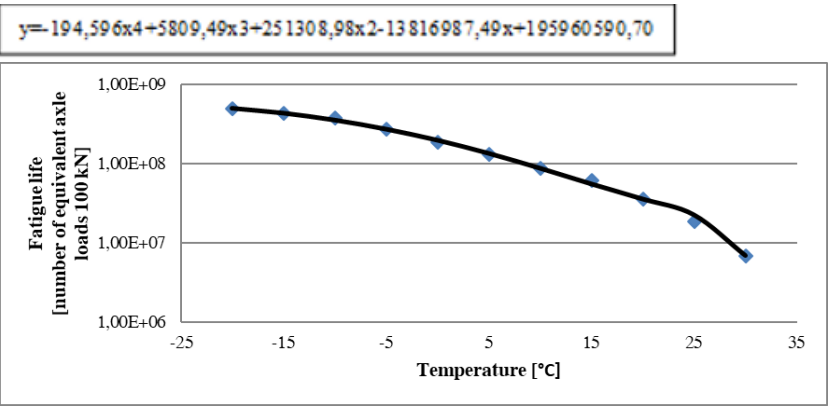

Fig. 6. The resulting fatigue curve from the calculations with use of AASHTO 2004 criterion

The annual equivalent temperature values calculated with the use of the Asphalt Institute fatigue criterion for different locations of meteorological station were presented in Table 6 .

Table 6. The annual equivalent temperature values calculated with the use of the Asphalt Institute fatigue criterion for different locations of meteorological station

\begin{tabular}{|c|c|c|c|}
\hline \multirow{2}{*}{ Location } & \multicolumn{3}{|c|}{ Equivalent temperature $\left[{ }^{\circ} \mathrm{C}\right]$} \\
\cline { 2 - 4 } & KR2 & KR4 & KR6 \\
\hline Bialystok & 16.9 & 15.4 & 15.7 \\
\hline Elblag & 17.2 & 16.0 & 16.2 \\
\hline Katowice & 17.9 & 16.6 & 16.8 \\
\hline Krosno & 17.6 & 16.3 & 16.5 \\
\hline Poznan & 18.2 & 16.9 & 17.1 \\
\hline Szczecin & 18.0 & 16.8 & 17.0 \\
\hline Swinoujscie & 17.4 & 16.2 & 16.4 \\
\hline Torun & 17.9 & 16.6 & 16.8 \\
\hline Warszawa & 18.2 & 16.8 & 17.0 \\
\hline Wroclaw & 18.3 & 17.2 & 17.6 \\
\hline
\end{tabular}

The method of calculations with use of the Asphalt Institute fatigue criterion has shown that annual equivalent temperature that can be used for asphalt pavement design process is equal to $17^{\circ} \mathrm{C}$ (rounded to $\left.1,0^{\circ} \mathrm{C}\right)$.

The annual equivalent temperature values calculated with the use of the AASHTO 2004 fatigue criterion for different locations of meteorological station were presented in Table 7.

Table 7. The annual equivalent temperature values calculated with the use of the AASHTO 2004 fatigue criterion for different locations of meteorological station

\begin{tabular}{|c|c|c|c|}
\hline \multirow{2}{*}{ Location } & \multicolumn{3}{|c|}{ Equivalent temperature $\left[{ }^{\circ} \mathrm{C}\right]$} \\
\cline { 2 - 4 } & KR2 & KR4 & KR6 \\
\hline Bialystok & 16.1 & 16.1 & 14.4 \\
\hline Elblag & 16.5 & 16.5 & 14.9 \\
\hline Katowice & 17.1 & 17.2 & 15.5 \\
\hline Krosno & 16.8 & 16.9 & 15.2 \\
\hline Poznan & 17.4 & 17.6 & 15.9 \\
\hline Szczecin & 17.2 & 17.3 & 15.7 \\
\hline Swinoujscie & 16.6 & 16.7 & 15.2 \\
\hline Torun & 17.1 & 17.3 & 15.5 \\
\hline Warszawa & 17.4 & 17.6 & 15.7 \\
\hline Wroclaw & 17.6 & 17.9 & 16.1 \\
\hline
\end{tabular}

The method of calculations with use of the AASHTO 2004 fatigue criterion has shown that annual equivalent temperature that can be used for asphalt pavement design process is equal to $16^{\circ} \mathrm{C}$ (rounded to $\left.1,0^{\circ} \mathrm{C}\right)$.

\section{Conclusions}

Based on the results of calculations and analysis conducted, the following conclusions can be drawn:

1. The results of air temperature measurements from meteorological stations shown quite high variability between mean values of monthly temperatures during the past 32 years especially for winter months.

2. The equivalent temperature is very important issue in design process of asphalt pavements using mechanistic-empirical methods. It was shown that obtained values can vary between $10^{\circ} \mathrm{C}$ for Shell method through $15^{\circ} \mathrm{C}$ for the French method, the $16^{\circ} \mathrm{C}$ for method that use of the AASHTO 2004 fatigue criterion and finally the $17^{\circ} \mathrm{C}$ for method that use of the Asphalt Institute fatigue criterion.

3. It was found that the value of equivalent temperature mostly depends on the method of calculation and the collected air temperature data. It is very important to collect temperature data from meteorological stations located close to the area of designed pavement. 


\section{References}

1. M. Pszczola, J. Judycki, D. Rys, Transp. Res. Proc. 14, 738-747 (2016).

2. M. Pszczoła, D. Ryś, P. Jaskuła, Roads and Bridges, 16, pp. 245-269, (2017) doi: 10.7409/rabdim.017.016

3. T. Wang, L. Su, J. Zhai, INT J PAVEMENT ENG 15:5, pp. 402-408 (2014).

4. French Design Manual for pavement structures. Guide technique. Laboratoire Central des Ponts et Chaussées (LCPC), Service d'Etudes Techniques des Routes et Autoroutes (SETRA) Centre de la Sécurité et des Techniques Routiéres, (1997)

5. M.A. Miner, 'Cumulative damage in fatigue', J. Appl. Mech. 12, (1945), A159-A164.

6. A.I.M. Claessen, J.M. Edwards, P. Sommer, P. Uge, Asphalt pavement design. The Shell Method. In: Proceedings of the 4th International Conference on the Structural Design of Asphalt Pavements, University of Michigan, Ann Arbor, USA, pp. 1-36, (1977)

7. I. Fi, L. Pethö, Periodica Polytechnica Civil Engineering 52/2, pp. 91-96 (2008)

8. J. Judycki, P. Jaskuła, M. Pszczoła, D. Ryś, M. Jaczewski, J. Alenowicz, B. Dołżycki, M. Stienss, Analizy i projektowanie konstrukcji nawierzchni podatnych i półsztywnych, (Eng. Analyses and design of flexible and semi-rigid pavements), Wydawnictwa Komunikacji i Łączności, Warszawa, ISBN 978-83-206-1928-7, (2014)

9. L. Pethö, Proceedings of the 25th ARRB Conference, Perth, Australia (2012)

10. M.W. Witczak Proceedings of the 3rd International Conference on the Structural Design of Asphalt Pavements, pp. 550-567 (1972)

11. A. Pięta Analysis of equivalent temperature for design of pavement structure", M.Sc. Thesis at Gdansk University of Technology, (2017) (in Polish)

12. Guide for Mechanistic-Empirical Design of New and Rehabilitated Pavement Structures. Final Document. Appendix II-1. Calibration of Fatigue Cracking Models for Flexible Pavements., NCHRP, TRB, NRC, (2004) 